\title{
FARMER OBSERVATIONS ON THE IMPACT OF CLOVER ROOT WEEVIL (SITONA LEPIDUS) ON WAIKATO FARMS
}

\author{
B. WILLOUGHBY and F. KETTLEWELL
}

\author{
AgResearch, Ruakura Research Centre, Private Bag, Hamilton
}

Clover root weevil (Sitona lepidus), first identified in the Waikato in 1996, is currently distributed through the Auckland, Waikato and Bay of Plenty regions. This pest is perceived to be having a major effect on the sustainability of white clover in pastures in these regions. Two farmer surveys conducted in autumn 1996 and spring 1997 elicited over 300 responses. The surveys, in the form of a questionnaire, sought to define farmer perceptions of the impact of clover root weevil in terms of clover damage and survival. Farmer observations on the role of pasture age, pasture pugging, soil type, fertiliser inputs and management practices on clover productivity were sought. The survey demonstrated that clover content was generally lower in pastures where clover root weevil was present; however if red clover was present the estimations of clover content were generally higher. In the absence of clover root weevil, the highly stocked paddocks (3.4 - 3.7 cows/ha) had the greatest proportion with a high clover content $(20-30 \%)$. However, in the presence of the weevil, the peak proportion was reduced to $10-20 \%$ clover content. Farmer observations suggested that soil type may affect expression of damage by clover root weevil. Peat and clay based soils had substantially less clover cover in the presence of clover root weevil than ash based soils. 